\title{
Pollutants Induced Cancer in Experimental Animals
}

\author{
Rajesh K. Bhaskar ${ }^{1}$ \\ ${ }^{1}$ School of Biosciences, Mahatma Gandhi University., P. D. Hills.P.O., Kottayam, Kerala., India
}

\begin{abstract}
Pollution is the greatest threat posed to humanity and biosphere as a whole.Envionmental factors and genetic suspectibility play impotant role in many human cancers.There is an increasing global concern on the upward trend of cancer attributable to the environmental causes. The role played by liver in the removal of substances from the portal circulation makes it susceptible to first and persistent attack by offending agents like viruses, chemicals, toxins in food, peroxides, drugs, environmental pollutants etc.culminating in liver pathology.On exposure to xenobiotics, the liver of vertebrates manage to eliminate such foreign compound as early as possible. During xenobiotic metabolism, highly reactive metabolites like peroxides, epoxides and other radicals are formed.
\end{abstract}

Keywords: Pollution, xenobiotics, biochemical markers, toxic chemicals, carcinogenesis, toxicity

\section{Introduction}

These chemicals have reduced suffering and increased yields when used correctly but there is also certainly that those same chemicals have been implicated in serious adverse effects both in man and in the environment. Exposure of living organisms to xenobiotics leads to interactions between these chemicals and biological systems, which may give rise to biochemical disturbances or/and adaptive responses (Masfaraud et al, 1992). Thousands of chemicals and chemical formulations are involved and most of them are poisonous to organisms other than those that man intends to kill. Cancer is a complex process, and its causes are poorly understood (Pitot, 1986).Cancer cells have rapid phenotypic rate, invasion of new cellular territories, high metabolic rate and abnormal shape.Biochemical markers are increasingly used to identify the incidence of effects caused by xenobiotic (Otitoju and Onwurah, 2007). Those chemicals identified as being causally associated with cancers in humans have all been shown to produce cancer in laboratory animals; in every instance atleast onsite of cancer was common to both mammalian species (Tomatis, 1979., 1989 and Huff, J. E.1992).

\section{Chemical Carcinogenesis}

All chemicals in the industrial waste are toxic to animals and may cause death or sub-lethal pathology of the liver, kidney, heart, reproductive systems, respiratory systems and nervous systems.Cancer is the second leading caue of death in industrialized countries. The nature of this genetic damage is poorly understood, although considerable progress has been made in recent years to clarify the role of oncogenes and antioncogenes in neoplastic transformation. Cancers differ so markedly in their characteristics of differentiation, growth rate, and local and distant (metastatic) invasiveness, that one can only conclude that the normal growth control mechanisms must be exceedingly complicated. The liver and kidney are especially vulnerable to many toxic substances (Doull et al, 1980).

Major Effects of Pollutants on the Society

\begin{tabular}{|c|c|c|}
\hline Type of effect & Nature of effect & Pollutants involved \\
\hline $\begin{array}{l}\text { On human health, } \\
\text { due to Inhalation } \\
\text { of airborne } \\
\text { chemicals. }\end{array}$ & $\begin{array}{l}\text { Pulmonary } \\
\text { dysfunction, } \\
\text { respiratory disease } \\
\text { and mental } \\
\text { retardation }\end{array}$ & $\begin{array}{l}\text { Ozone, } \\
\text { Sulfurdioxide, } \\
\text { Nitrogen dioxide, } \\
\text { particulatematter, } \\
\text { Carbonmonoxide, } \\
\text { Toxic elements. }\end{array}$ \\
\hline $\begin{array}{l}\text { Effects on human } \\
\text { health, due to } \\
\text { atmospheric } \\
\text { deposition or } \\
\text { leaching and later } \\
\text { ingestion of } \\
\text { airborne or } \\
\text { soilborne } \\
\text { chemicals via } \\
\text { drinking water, } \\
\text { fish, or other } \\
\text { products }\end{array}$ & $\begin{array}{l}\text { Diarrhea and } \\
\text { mental retardation } \\
\text { in children and } \\
\text { poisoning of adults } \\
\text { by lead, mercury, } \\
\text { copper, cadmium } \\
\text { or other toxic } \\
\text { elements. }\end{array}$ & $\begin{array}{l}\text { Toxic elements.Acid } \\
\text { deposition resulting } \\
\text { from emissions of } \\
\text { sulfurdioxide and } \\
\text { nitrogendioxides. }\end{array}$ \\
\hline $\begin{array}{l}\text { Damage to } \\
\text { engineering } \\
\text { materials, statuary } \\
\text { monuments and } \\
\text { other cultural } \\
\text { resources }\end{array}$ & $\begin{array}{l}\text { Increased corrosion } \\
\text { of metals; } \\
\text { accelerated } \\
\text { weathering of tone } \\
\text { and masonry; } \\
\text { soiling of textiles, } \\
\text { glass, paints and } \\
\text { other materials; } \\
\text { deterioration of } \\
\text { paints, plastics and } \\
\text { rubber. }\end{array}$ & $\begin{array}{l}\text { Sulfur dioxide, } \\
\text { Nitrogen dioxide, } \\
\text { Particulatematter, } \\
\text { Ozone, Acid } \\
\text { deposition }\end{array}$ \\
\hline $\begin{array}{l}\text { Increased haze in } \\
\text { the atmosphere }\end{array}$ & $\begin{array}{l}\text { Decreased } \\
\text { visibility in urban } \\
\text { and rural areas, } \\
\text { with attendant } \\
\text { decreases in safety } \\
\text { of air transport and } \\
\text { enjoyment of } \\
\text { scenic vistas from } \\
\text { aircrafts and in } \\
\text { arks. }\end{array}$ & $\begin{array}{l}\text { Particulatematter, } \\
\text { Sulfur dioxide, } \\
\text { Nitrogendioxide, } \\
\text { Volatile organic } \\
\text { compounds, } \\
\text { Photochemical } \\
\text { oxidants. }\end{array}$ \\
\hline $\begin{array}{l}\text { Acidification of } \\
\text { lakes, streams, } \\
\text { ground waters } \\
\text { and soils. }\end{array}$ & $\begin{array}{l}\text { Death and } \\
\text { reproductive } \\
\text { failure in fresh } \\
\text { water fish; } \\
\text { decreased fertility } \\
\text { of soil. }\end{array}$ & $\begin{array}{l}\text { Sulfur dioxide, } \\
\text { Nitrogen dioxide, } \\
\text { Acid deposition }\end{array}$ \\
\hline $\begin{array}{l}\text { Fumigation of } \\
\text { crops and forests } \\
\text { near point sources } \\
\text { of pollutants }\end{array}$ & $\begin{array}{l}\text { Decreased growth } \\
\text { and } \\
\text { yield of crops and } \\
\text { forests }\end{array}$ & $\begin{array}{l}\text { Ozone, } \\
\text { Sulfurdioxide, } \\
\text { Nitrogen dioxide, } \\
\text { Toxic elements }\end{array}$ \\
\hline
\end{tabular}

\section{Volume 5 Issue 3, March 2016}




\section{International Journal of Science and Research (IJSR) \\ ISSN (Online): 2319-7064}

Index Copernicus Value (2013): 6.14 | Impact Factor (2014): 5.611

\begin{tabular}{|l|l|l|}
\hline $\begin{array}{l}\text { Regional changes } \\
\text { in the health and } \\
\text { productivity of } \\
\text { forests. }\end{array}$ & $\begin{array}{l}\text { Decreased growth, } \\
\text { increased mortality } \\
\text { and predisposition } \\
\text { of forest trees to } \\
\text { biotic and abiotic } \\
\text { stress factors. }\end{array}$ & $\begin{array}{l}\text { Ozone, } \\
\text { Nitrogendioxide, } \\
\text { Ammonia and } \\
\text { ammoni um } \\
\text { nitrogen, nitrogen, } \\
\text { SO2, Acid } \\
\text { deposition, } \\
\text { particulate matter }\end{array}$ \\
\hline $\begin{array}{l}\text { Fertilization of } \\
\text { crops, forests and } \\
\text { surface waters. }\end{array}$ & $\begin{array}{l}\text { Increased } \\
\text { productivity of } \\
\text { crops, forests and } \\
\text { surface waters. }\end{array}$ & $\begin{array}{l}\text { Ammonia and } \\
\text { ammonium nitrogen, } \\
\text { sulphur dioxide, } \\
\text { Acid deposition, } \\
\text { particulate matter. }\end{array}$ \\
\hline
\end{tabular}

\section{Pollutants and its effect in the health}

Biological Pollutants-were living organisms.

Source: Infectious agents like bacteria or viruses, molds (fungi), pollen, dust mites, and animal dander (minute scales from hair, skin or feathers).

Health Effect: Allergic (range from slightly uncomfortable to life-threatening, asthma attack), infectious, toxic.

\section{- Environmental Tobacco Smoke}

Source: Cigarette, pipe, and cigar smoking, and smoke exhaled by the smoker.

Health Effects: Exposure to secondhand smoke can cause eye, nose, and throat irritation; headaches; lungcancer; may contribute to heart disease. Infants and children are at risk of lower respiratory tract Infections (such as bronchitis and pneumonia), ear infections, decreased lungfunction, increased severity and frequency of asthma episodes.

\section{- Radon - A gaseous radioactive element.}

Source: cracks in the foundation floor and walls, drains, and other openings, earth and rock beneath home, well water, building materials.

Health Effect: Cause of lung cancer, smokers are at higher risk.

\section{- Carbon Monoxide CO)}

A colorless and odorless but highly toxic gas (toxic substance) which is produced during incomplete combustion of coal oil and natural gas and incineration of garbage and other solid and liquid wastes.

Carbon monoxide inhibits respiration in human and other animals. It is so concern to the society mostly in urban areas, where it accumulates in stagnant air mainly from the transportation vehicles.

Source:Home appliances (using wood, gas or fuel), heating systems, generators and other gasoline powered equipment, leaking chimneys and furnaces, gas water heaters, wood stoves, gasstoves automobile exhaust from attached garages, and Environmental Tobacco smoke.

Health Effect: worsen cardiovascular conditions and produce fatigue, disorientation, impaired vision, headache, weakness, confusion, nausea and dizziness.Very high levels can cause death.

\section{- Sulfur Dioxide}

A colorless gas produced during combustion of sulfur containing materials such as coal, oil and biomass, and during smelting of sulfide metal ores. $\mathrm{SO}_{2}$ is emitted mainly by large stationary sources such as fossil fueled power plants, metal smelters and other industrial and commercial installations. Biomass burning is an important source of sulfur oxides in tropical regions of the world.

\section{- Formaldehyde}

One of the large families of chemical compounds called volatile organic compounds or 'VOCs'.

Source: Building material, household products, fuelburning appliances (like gas stoves), pressed wood products (hardwood plywood wall paneling, particleboard, fiberboard and furniture), permanent-press qualities to clothing and draperies, as a component of glues and adhesives, and as a preservative in some paints and coating products.

Health Effect: coughing; eye, nose, and throat irritation; skin rashes, headaches, and dizziness. Eye, nose, and throat irritation; wheezing and coughing; fatigue; skin rash; severe allergic reactions that cause cancer.May also cause other effects listed under"organic gases."

\section{- Pesticides}

Source: mixture of substances intended for preventing, destroying, repelling, or mitigating any pest (insecticides, disinfectants etc.) products used on lawns and gardens that drift or are tracked inside the house.

Health Effect: Irritation (eye, nose, and throat), increased risk of cancer, damage to central nervous system and kidney.

\section{- Asbestos}

It is a group of fibrous metamorphic minerals.

Source: Deteriorating damaged or disturbed insulation, fireproofing, acoustical materials, and floor tiles.

Health Effect: In long-term risk of chest and abdominal cancers and lung diseases.Smokers are at higher risk of developing Asbestos-induced lung cancer.

\section{- Lead}

It is a naturally occurring bluish-gray metal found in small amounts in the earth's crust. 


\section{International Journal of Science and Research (IJSR) \\ ISSN (Online): 2319-7064}

Index Copernicus Value (2013): 6.14 | Impact Factor (2014): 5.611

Source: Lead-based paint, contaminated soil, dust, and drinking water.

Health Effect: At lower levels of lead can cause adverse health effects on the central nervous system, kidney and blood cells.

Lead at high levels can cause convulsions, coma, and even death.

\section{- Respirable Particles}

Source: Fireplces, woodstoves, and kerosene heaters.

Health Effect: respiratory infections and bronchitis, Irritation (eye, nose, and throat), lung cancer.

\section{- Organic Gases}

Source: widely used as ingredients in household products like paints, paint strippers, varnishes, wax, aerosol sprays, cleansers and disinfectants, moth repellents and air fresheners, stored fuels and automotive products, drycleaned clothing.

Health Effects: Loss of coordination, nausea; damage to liver, kidney, and central nervous system, Irritation (eye, nose, and throat), some cause cancer.

\section{- Nitrogen Dioxide (NOx)}

Two colorless gases ( $\mathrm{NO}$ and $\mathrm{NO}_{2}$ ) produced in any high temperature process such as combustion of coaloil, gasoline and natural gas.Nitrogen Dioxides are emitted by both stationary sources and transportation vehicles.

Source:Un-vented kerosene heaters, gas stoves and heaters, as well as tobacco smoke.Automobile exhaust, usually in attached garages.In tropical countries, burning of biomass is also an important source of $\mathrm{NO}_{\mathrm{X}}$.

Health Effect: high concentrations or continued exposure to low levels might increase the risk ofrespiratory infection.

\section{- Toxic elements}

Heavy metals and other toxic elements such as lead, cadmium, nickel, mercury and fluorine are released mainly by large metal smelters and by transportation vehicles using leaded gasoline.

\section{- Volatile Organic Compounds (VOC)}

A wide variety of carbon compounds ranging from such simple molecules such as ethylene, gasoline and cleaning and painting solvents to very complex molecules such as pesticides.VOC are emitted by many (usually small) stationary and mobile sources.

\section{- Particulate matter (PM)}

A catch-all category of pollutants ranging from very coarse "fugitive dust" particulates that cause soiling of textiles, windows, paints etc.to very fine aerosol particles that cause atmospheric haze or are drawn into the lungs where they induce respiratory diseases.The particulate matter, particularly that less than $10 \mu$ in size, can pass through the natural protective mechanism of human respiratory system and plays an important role in genesis and augmentation of allergic disorders.

\section{- Acid deposition}

A variety of acidic and acidifying substances produced when gaseous $\mathrm{SO}_{2}, \mathrm{NO}_{\mathrm{X}}, \mathrm{HCl}$ and certain other airborne chemicals interact with oxygen, ammonia and moisture to give aqueous solutions or aerosols of sulfuric, nitric and hydrochloric acids. Acidification of ecosystems also occurs when ammonia and ammonium sulfate aerosol and certain other ammonium compounds are taken up plants, animals or microorganisms after deposition into ecosystems.

\section{- "Greenhouse" Gases}

A variety of energy absorbing gases that alter the radiative energy balance of the earth and thus induce a general warming of the atmosphere.The most important of these climate altering gases include carbondioxide, water vapor, certain oxides of nitrogen (nitrous oxides and nitrogendioxide), sulferdioxide, methane, chloflourocarbons and ozone.These substances are released from a wide variety of natural and human sources that include burning of fossil fuels and deforestation in the case of carbon dioxide.

\section{Classes of Poisons}

I. Corrosives (mechanical)
A.Acids
B. Bases
C. Oxidizers
D. Reducing Agents
II. Metabolic Poisons (energy)

A. Specific Biochemical Inhibitors

B. Heavy Metals

III.Neurotoxins (nervous system)
A.Anticholinesterases
B.Acetylcholine Antagonists
C.Cell Membrane Disrupters
IV.Teratogens (birth defects)
$\mathrm{V}$. Mutagens (DNA damage)
VI. Carcinogens (cancer) 
Index Copernicus Value (2013): 6.14 | Impact Factor (2014): 5.611

\begin{tabular}{|l|l|}
\hline Acutely Toxic Chemicals & Toxic Levels \\
\hline & \\
Acrolein & $2 \mathrm{ppm}$ \\
Arsine & $3 \mathrm{ppm}$ \\
Chlorine & $10 \mathrm{ppm}$ \\
Diazomethane & $2 \mathrm{ppm}$ \\
Diborane (gas) & $15 \mathrm{ppm}$ \\
Hydrogen cyanide & $50 \mathrm{ppm}$ \\
Hydrogen flouride & $30 \mathrm{ppm}$ \\
Methyl flourosulfonate & $5 \mathrm{ppm}$ \\
Methyl isocyanate & $3 \mathrm{ppm}$ \\
Nickel carbonyl & $2 \mathrm{ppm}$ \\
Nitrogen dioxide & $20 \mathrm{ppm}$ \\
Osmium tetroxide & $1 \mathrm{mg} / \mathrm{m}^{3}$ \\
Ozone & $5 \mathrm{ppm}$ \\
Phosgene & $2 \mathrm{ppm}$ \\
Sodium azide & $20 \mathrm{ppm}$ \\
Sodium cyanide(as CN) & $25 \mathrm{mg} / \mathrm{m}^{3}$ \\
\end{tabular}

\begin{tabular}{|c|c|c|c|}
\hline Substance & $\begin{array}{c}\text { Listed in } \\
\text { CAPCOA(1993) }\end{array}$ & \begin{tabular}{|c|} 
Hazard \\
Index \\
target(s) \\
\end{tabular} & Human Data \\
\hline 1 & Acrolein & 0.06 & $\begin{array}{l}\text { Respiratory system; } \\
\text { eyes }\end{array}$ \\
\hline 2 & Arsenic & 0.03 & $\begin{array}{l}\text { Development; } \\
\text { Cardiovascular } \\
\text { system; Nervous } \\
\text { system }\end{array}$ \\
\hline 3 & Butadiene & 20 & Reproductive system \\
\hline 4 & Cadmium & 0.02 & $\begin{array}{l}\text { Kidney; respiratory } \\
\text { system }\end{array}$ \\
\hline 5 & Carbon tetrachloride & 40 & $\begin{array}{l}\text { Alimentarysystem; } \\
\text { development;nervous } \\
\text { system }\end{array}$ \\
\hline 6 & Chlorine dioxide & 0.6 & Respiratory system \\
\hline 7 & Chlorobenzene & 1000 & $\begin{array}{l}\text { Alimentary system; } \\
\text { kidney; reproductive } \\
\text { system }\end{array}$ \\
\hline 8 & Chromium hexavalent: & 0.2 & Respiratory system \\
\hline 9 & $\begin{array}{l}\text { Chromic trioxide } \\
\text { (as chromic acid mist) }\end{array}$ & 0.002 & Respiratory system \\
\hline 10 & Cresol mixtures & 600 & Nervous system \\
\hline 11 & Dichlorobenzene (1, 4- & 800 & $\begin{array}{l}\text { Nervous ystem; } \\
\text { respiratory system; } \\
\text { alimentary system; } \\
\text { kidney }\end{array}$ \\
\hline 12 & Dichloroethylene & 70 & Alimentary system \\
\hline 13 & $\begin{array}{l}\text { Dimethylformamide(N } \\
\mathrm{N}-\text { ) }\end{array}$ & 80 & $\begin{array}{l}\text { Alimentary } \\
\text { system;respiratory } \\
\text { system }\end{array}$ \\
\hline 14 & Epichlorohydrin & 3 & $\begin{array}{l}\text { Respiratory system; } \\
\text { eyes }\end{array}$ \\
\hline 15 & Epoxybutane (1, 2-) & 20 & $\begin{array}{l}\text { Respiratory system; } \\
\text { cardiovascular system }\end{array}$ \\
\hline 16 & Ethylene dichloride & 400 & $\begin{array}{l}\text { Alimentary system } \\
\text { (liver) }\end{array}$ \\
\hline 17 & Ethylene oxide & 30 & Nervous system \\
\hline 18 & Glutaraldehyde & 0.08 & Respiratory system \\
\hline 19 & Hydrazine & 0.2 & $\begin{array}{l}\text { Alimentary } \\
\text { system;endocrine } \\
\text { system }\end{array}$ \\
\hline 20 & $\begin{array}{l}\text { Methylene Diphenyl } \\
\text { Isocyanate }\end{array}$ & 0.7 & Respiratory system \\
\hline 21 & Phthalic anhydride & 20 & Respiratory system \\
\hline 22 & Toluene diisocyanates & 0.07 & Respiratory system \\
\hline
\end{tabular}

Chronic Reference Exposure Levels Adopted by OEHHA, January 2001

\begin{tabular}{|l|}
\hline $\begin{array}{l}\text { Human carcinogenesis and levels of evidence of } \\
\text { carcinogenicity }\end{array}$ \\
\hline $\begin{array}{l}\text { Level } 1 \text { Chemicals shown epidomiologically as casually } \\
\text { associated with cancers in humans. }\end{array}$ \\
\hline $\begin{array}{l}\text { Level } 2 \text { Chemicals shown epidomilogically as possible } \\
\text { associated with cancers in humans, and confirmed experimentally } \\
\text { as causing cancers in laboratory animals. }\end{array}$ \\
\hline $\begin{array}{l}\text { Level } 3 \text { Chemicals shown experimentally as causing cancers in } \\
\text { laboratory animals. }\end{array}$ \\
\hline $\begin{array}{l}\text { Level } 4 \text { Chemicals shown to exhibit molecular mechanisms } \\
\text { similar to those in levels1-3 }\end{array}$ \\
\hline
\end{tabular}

Chemicals $=$ mixtures of chemicals, exposure circumstances, and/or occupations.

(Huff, 1993)

\begin{tabular}{|l|l|l|}
\hline \multicolumn{3}{|c|}{ Measurement of Acute Toxicity } \\
\hline Classification & $\begin{array}{l}\mathrm{LD}_{50}-\mathrm{Wt} / \mathrm{Kg} \\
\text { Single Oral Dose } \\
\text { Rat }\end{array}$ & $\begin{array}{l}\mathrm{LC}_{50}-\mathrm{PPM} \\
4 \mathrm{Hr} \text { Inhalation } \\
\text { Rat }\end{array}$ \\
\hline Extremely Toxic & $5-50 \mathrm{mg}$ or less & $<10$ \\
\hline Highly Toxic & $5-50 \mathrm{mg}$ & $1-100$ \\
\hline Moderately Toxic & $50-500 \mathrm{mg}$ & $100-1,000$ \\
\hline Slightly Toxic & $0.5-5$ grams & $1,000-10,000$ \\
\hline $\begin{array}{l}\text { Practically Non- } \\
\text { toxic }\end{array}$ & $5-15$ grams & $10,000-100,000$ \\
\hline Relatively Harmless & 15 grams or more & $>100,000$ \\
\hline
\end{tabular}

\section{Measuring Toxicity: $\mathrm{LD}_{50}$ and $\mathrm{LC}_{50}$}

Toxicity tells how poisonous a substance is the rating given to each substance to show toxicity. For oral and dermal exposures, the rating is called an $L_{50}$.For respiratory exposure the term $\mathrm{LC}_{50}$ is used. Toxicity measured in milligrams (mg); the weight of the animal is measured in kilograms $(\mathrm{kg})$. The $\mathrm{LD}_{50}$ or $\mathrm{LC}_{50}$ number stands for the pesticide dose (in milligrams) for each kilogram of body weight.

\section{Exposure Reduction}

Reduction of pesticide exposure by inhalation, or by other routes that depend on the transfer of residues through the air, can be accomplished by a variety of approaches (eg.Agricultural Research Institute, 1988). Any increase in efficient delivery of chemical to the intended target that minimize off-target drift during application will increase exposure to airborne residues.Specific samples include the use of granular formulations, electrostatic spray technology, the use of sensors that direct spraying in response to variations in target and greater use of soil in corporation and chemigation, both of which reduce contact of the chemical with air.

\section{Animal Tests for Developmental Toxicity}

The traditional measures of developmental toxicity in animals and humans include malformations, decreased body weight at birth, death of the embryo, fetus or neonate, and alterations of function.Many chemicals shown initially to be developmental toxicants or teratogens (ie.inducing major structural malformations) in laboratory 


\section{International Journal of Science and Research (IJSR) \\ ISSN (Online): 2319-7064 \\ Index Copernicus Value (2013): 6.14 | Impact Factor (2014): 5.611}

animals have later been demonstrated to cause the same effects in humans; many agents known to be developmental toxicants in humans act similarly in laboratory animals.

\section{Genotoxicity}

The distinctive laddering pattern of the DNA is due to the endonuclease cleavage. Electrophorectic analysis of DNA by DNA laddering techniques allows confirmation of the presence of degraded DNA.When resolved in the agarose gel electrophoresis these DNA fragments appear as a 'nucleosomal ladder', a widely recognized hallmark of apoptotic cell death is seldom detectable by ethidium bromide staining under physiological conditions, therefore we adapted a very sensitive method based on radioactive end labeling of extracted DNA.A powerful tool to elucidate the activation pathway of a carcinogen is to characterize and quantify the DNA adducts it forms and to determine the factors that enhance or inhibit adduct formation (Arlt, 2002).

\section{Conclusion}

Cancer is a complex set of more than 200 diseases with many causes and multiple stages and histological grades of malignancy. Acute lung damage caused by a variety of chemicals beloging to different classes and presumably having different mechanisms of initial toxicity may thus be greatly enhanced by a second toxic agent which interferes with recovery of the damaged alveolar tissue.Among other potential health effects, exposure to these largely carbonaceous aerosol and gaseous pollutants has been found most strongly to be associated with acute respiratory infections in young children and chronic obstructive pulmonary disease and lung cancer in adult women.Some toxicants cause direct injury to liver and others connect chemicals into toxic substances through metabolic conversion (Bhaskar, 2012).

\section{References}

[1] Agricultural Research Institute.Improving On-Target placement of Pesticides:A Conference.June, 13-18, Bthesda, MD, 1988.

[2] Arlt VM, Glatt H, Muckel E, Pabel U, Sorg BL, Schmeiser HH, and Phillips DH .Metabolic activation of the environmental contaminant 3-nitrobenzanthrone by human acetyltransferases and sulfotransferase.Carcinogenesis 23: 1937-1945, 2002.

[3] Bhaskar, R.K. Liver as target organs of carcinogenesis by xenobiotics. J.Biotechnol.Biomater.2 (6), 251, 2012.

[4] Cowling.Critical review discussion: Effects of air pollution on forests.JAir Pollut .Control Assoc.35:916-919, 1985.

[5] Doull, J., Klassen, C.D., and Amdur, M.O.Casarett and Doull's toxicology, $2^{\text {nd }}$ ed.New York, 1980.

[6] Huff, J.Chemicals and Cancer in Humans: First Evidence in Experimental Animals .Environmental Health Perspectives. Vol.100, pp.201-210, 1993.

[7] Huff, J. E., and Rall, D. P. Relevance to humans of carcinogenesis results from laboratory animal toxicology studies. In: Maxcy-Rosenau-Last's Public Health and Preventive Medicine (J.M.Last and R.B.Wallace, Eds.), 13th ed.Appleton \& Lange, Norwalk, Connecticut,, pp.433-440, 453-457, 1992

[8] Masfaraud, Aksnes, A. and Njaa, L.R.Aquat.Toxic.450:156, 1992.

[9] Otitoju $\mathrm{O}$ and Onwurah INE.Glutathione-STransferase (GST) activity as a biomarker in ecological risk assessment of pesticide contaminated environment.African J Biotech 6 (12):1455-1459, 2007.

[10] Pitot, H.Fundamentals of Oncology, Marcel Dekker Inc., NewYork, 1986.

[11] Tomatis, L.The predictive value of rodent carcinogenicity tests in the evaluation of human risks. Annu. Rev. Pharmacol. Toxicol. 19: 511-530, 1979.

[12] Tomatis, L., Aitio, A., Wilbourn, J., and Shuker, L.Human carcinogens so far identified. Jpn. J.Cancer Res.80:795-807, 1989 